\title{
Integrated Water Resources Management in the Maltese Islands
}

\section{Gestione integrata delle risorse idriche nelle isole maltesi}

\author{
Manuel Sapiano
}

\begin{abstract}
Riassunto: Le isole maltesi presentano un caso di estrema indisponibilità delle risorse naturali di acqua dolce, dove le risorse disponibili non sono sufficienti per soddisfare in modo sostenibile la domanda nazionale di acqua. Ciò a causa delle condizioni climatiche semi-aride delle isole e della piccola massa terrestre che preclude la formazione di corpi idrici superficiali come fiumi e laghi. In effetti, i fragili corpi idrici sotterranei dell'isola sono gli unici sistemi di acqua dolce naturalmente rinnovabili disponibili per lo sviluppo delle risorse di approvvigionamento idrico. Inoltre, l'elevata densità di popolazione delle isole si traduce in un'elevata domanda specifica di acqua per soddisfare le esigenze della popolazione, le loro attività economiche e gli ecosistemi dipendenti dall'acqua.
\end{abstract}

Al fine di affrontare queste condizioni difficili, Malta ha sviluppato un quadro di gestione integrata dell'acqua basato sull'uso congiunto dell'aumento dell'approvvigionamento idrico e delle misure di gestione della domanda idrica. In questo quadro, Malta promuove l'utilizzo di risorse idriche non convenzionali come la desalinizzazione dell'acqua di mare e il recupero delle acque reflue per integrare le risorse naturali di acqua dolce. Lutilizzo di risorse idriche non convenzionali consente di soddisfare le richieste idriche nazionali, garantendo nel contempo l'uso sostenibile delle risorse naturali di acqua dolce. Le misure di gestione della domanda idrica garantiscono che l'uso dell'acqua sia mantenuto a livelli altamente efficienti, riducendo così la necessità di produzione di acqua da queste risorse alternative aggiuntive.

Lo sviluppo di questo quadro di gestione dell'acqua è delineato nel secondo piano di gestione del bacino idrografico di Malta. Pertanto, sostiene il raggiungimento degli obiettivi ambientali della Direttiva Quadro sulle acque dell'Unione Europea nel di-

Keywords: Malta, Water Scarcity, Integrated Management, Supply Augmentation, Demand Management.

Parole chiave: Malta, carenza idrica, gestione integrata, aumento della fornitura, gestione della domanda.

\section{Manuel SAPIANO恝"}

Energy and Water Agency, Malta

e-mail: manuel.sapiano@gov.mt

Ricevuto/Received: 20 September 2020-Accettato/Accepted: 28 September 2020 Pubblicato online/Published online: 30 September 2020

This is an open access article under the CC BY-NC-ND license:

http://creativecommons.org/licenses/by-nc-nd/4.0/

(C) Associazione Acque Sotterranee 2020 stretto del bacino del fiume Malta. Il suo contesto integrato sostiene anche gli sforzi di adattamento di Malta ai cambiamenti climatici, i cui impatti dovrebbero aggravare ulteriormente le sfide idriche che l'isola deve affrontare.

Lesperienza di Malta in materia di gestione idrica evidenzia l'importanza dello sviluppo e dell'attuazione di piani di gestione integrata dell'acqua. La protezione efficace delle risorse naturali di acqua dolce come le risorse idriche sotterranee delle isole non può essere garantita se queste vengono affrontate isolatamente, ma può essere raggiunta solo attraverso l'applicazione di tali piani integrati che affrontano la sostenibilità e la sicurezza dell'approvvigionamento idrico su base nazionale.

Abstract: : The Maltese islands present a case of extreme natural freshwater resources unavailability where available resources are not sufficient to sustainably meet the national water demand. This due to the islands' semi-arid climatic conditions and small land-mass which preclude the formation of surface water bodies such as rivers and lakes. In fact, the island's fragile groundwater bodies are the only naturally renewable freshwater systems available for the development of water supply resources. Furthermore, the islands high population density results in a bigh specific demand for water to address the requirements of the population, their economic activities and water dependent ecosystems. In order to address these challenging conditions Malta has developed an integrated water management framework based on the conjunctive use of water supply augmentation and water demand management measures. Under this framework, Malta promotes the application of Non Conventional Water Resources such as the desalination of sea-water and the reclamation of wastewaters to supplement natural freshwater resources. The application of Non Conventional Water Resources enables national water demands to be met, whilst ensuring the sustainable use of natural freshwater resources. Water Demand Management measures ensure that water use is kept at highly efficient levels, thereby reducing the need for the production of water from these additional alternative resources.

The development of this water management framework is outlined in Malta's 2nd River Basin Management Plan. It therefore supports the achievement of the EU's Water Framework Directive's environmental objectives in the Malta River Basin District. Its integrated context also supports Malta's adaptation efforts to climate change, whose impacts are expected to further exacerbate the water challenges facing the island. Malta's water management experience highlights the importance of the development and implementation of integrated water management frameworks. The effective protection of natural freshwater resources such as the islands' groundwater resources cannot be ensured if these are addressed in isolation but can only be achieved through the application of such integrated frameworks which addresses the sustainability and security of water supply on a national basis. 


\section{Background}

The Maltese Islands are located in the central Mediterranean region, south of the Italian island of Sicily, and consist of the three main islands of Malta, Gozo and Comino with a total area of $316 \mathrm{~km}^{2}$ (NSO 2020). The population of the country stands at 514,564 inhabitants, and hence the islands have a population density of 1618 inhabitants per $\mathrm{km}^{2}$, making them by far the most densely-populated member state of the European Union. As a result of this high population density, around $30 \%$ of the land area of the islands are classified as urban, including industrial and commercial use (Fig. 1).

The islands are poorly endowed with natural freshwater resources, and the availability of water resources has been, throughout the islands' history, an important limiting factor for their social and economic development. Scarcity of water resources arises due to a number of conditions, including the semi-arid Mediterranean climate with its characteristic low mean annual rainfall depths and high intra-annual variability in precipitation. The mean annual rainfall stands at around $550 \mathrm{~mm}$ and is mainly restricted between the months of September and April. In addition, the small size and geomorphology of the islands precludes the development of economically exploitable surface water resources whilst the high population density gives rise to a high specific demand for water per unit area of land. In fact, the availability of natural freshwater resources per capita is estimated to stand at around $70 \mathrm{~m}^{3} / \mathrm{cap} /$ year which is far below the $500 \mathrm{~m}^{3}$ threshold marking chronic water scarcity under the UN's water scarcity Falkenmark index (EWA 2015).

\section{Challenges in the Water Sector}

Malta's physical, climatic and demographic characteristics result in a high specific water demand for every square kilometre of national territory. This figure is currently estimated to stand at $175,000 \mathrm{~m}^{3} / \mathrm{km}^{2}$, way higher than the specific availability of natural freshwater resources which is estimated to stand at around $100,000 \mathrm{~m}^{3} / \mathrm{km}^{2}$.

Moreover, future long term social, demographic and economic trends (NSO 2020) highlight an increasing population, increasing levels of tourist arrivals, increased economic activity and improved standard of living conditions. All these factors are expected to lead to an increased national water demand, even if water consumption is kept at highly efficient levels.

Hence it is obvious that Malta is increasingly unable to address its national water demand from the available natural freshwater resources, even if efficient use of these limited water resources is made. In addition, the scarcity of water resources is also expected to be further exacerbated when the projected long-term reduction in the natural resource base due to climate change is taken into account. The predicted climate change impacts in the Maltese islands include a decrease in the mean annual rainfall, an increased prevalence of high intensity rain events which favour runoff instead of recharge and an increase in temperature resulting in increased natural water losses from the environment due to increased evapotranspiration rates (EWA 2015).

Therefore, both short- and long-term demand analysis predict an increased demand for water coupled with a lower availability of natural freshwater resources, further exacerbating the challenges facing Malta's water sector (EWA 2015).

\section{Strategic Water Management Framework}

In order to address these challenges and ensure a reliable and secure supply of water for the population, economic activities and the environment in the future, Malta has progressively

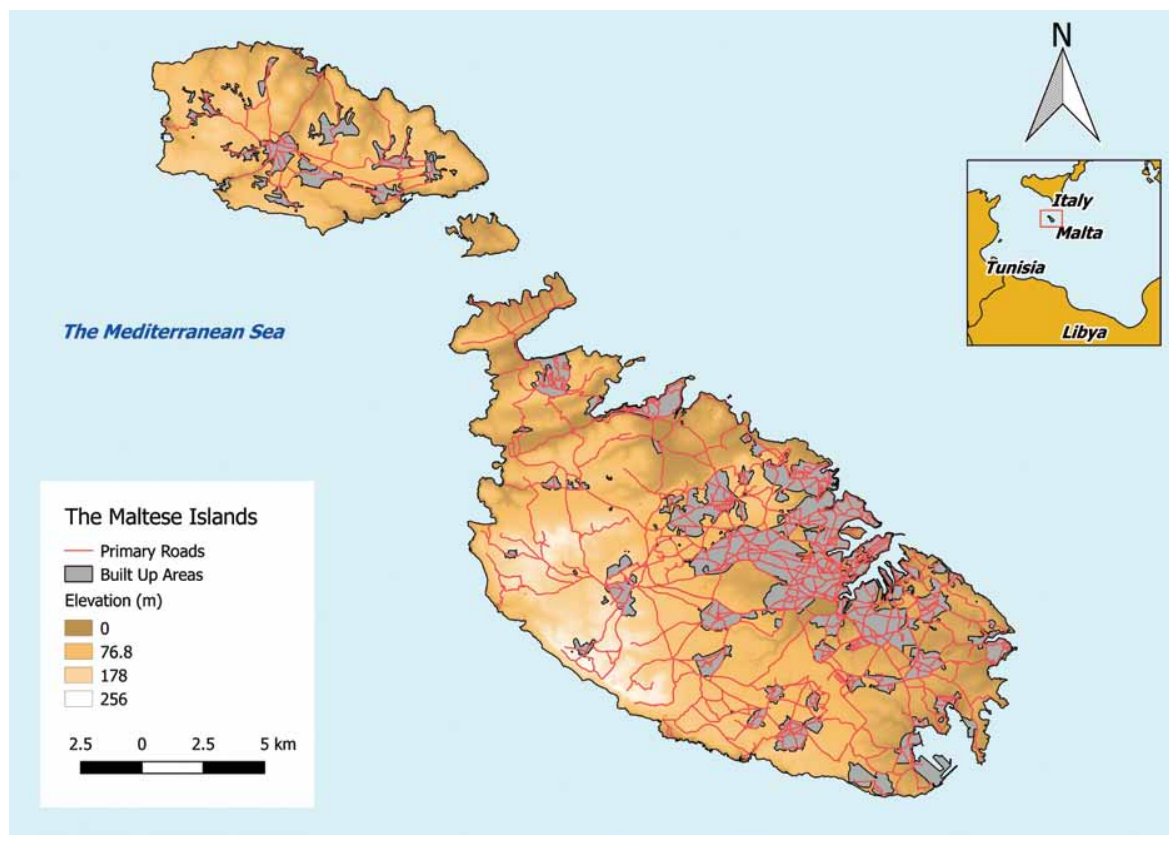

Fig. 1 - The Maltese islands.

Fig. 1 - Le isole Maltesi. 
developed a water policy framework (EWA 2015) based on the coordinated and integrated use of water demand management and water supply augmentation measures. This policy framework recognizes that natural water resources (mainly fresh-groundwater resources) are not sufficient, even if used sustainably, to address the national water demand.

The policy framework hence provides for the broadening of the national water supply resource base through the progressive introduction of non-conventional water resources (NCWR) such as the desalination of sea-water, the reuse of treated waste-waters and the harvesting of rainwater runoff in urban and rural areas. In addition, this policy framework also recognizes the important role of water demand management which by increasing the efficiency of water use reduces the need to produce additional water resources.

Hence in its $2^{\text {nd }}$ River Basin Management Plan ( $2^{\text {nd }} R B M P$ ) Malta recognizes the fact that its natural water resources (if used sustainably) are not sufficient to meet national demand and hence the production of alternative (non conventional) water resources is a necessity. In this context ensuring that water demand is kept at highly efficient levels gains increased importance to limit the need for alternative water resources.

\section{Water Resources Supply Base}

The semi-arid Mediterranean climate and the small landmass of the Maltese islands preclude the development of commercially exploitable surface water resources such as rivers and lakes. Therefore, groundwater is the main naturally renewable freshwater resource in the islands.

The layered geological formation (Fig. 2) of the island presents two porous limestone formations, the Upper and Lower Coralline/Globigerina Limestones, separated by a less permeable formation (Blue Clay formation). This geological context gives rise to two main typologies of aquifer systems. A series of small groundwater bodies perched in the Upper Coralline Limestone above the Blue Clay formation where this occurs above sea-level. The main sea-level groundwater bodies in the Lower Coralline/Globigerina Limestone

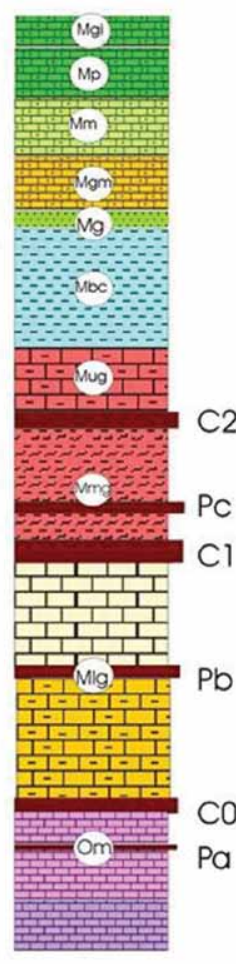

Mgi -Gebel Imbark Member: hard pale grey carbonates with sparse faunas $-4-25 \mathrm{~m}$

Mp - Tal-Pitkal Member: Fossiliferous pale grey , brown and brownish-grey coarse grained wackestones and packstones $0-30 \mathrm{~m}$

Mm - Mtarfa Member: Yellow to ream or chalky, massive to thickly bedded mudstones and packstones $12-16 \mathrm{~m}$

Mgm - Ghajn Melel Member: Massive bedded dark t pale brown packstones $-0-13 \mathrm{~m}$

Mg - Greensand Formation: grey to dark grey glauconitic sand $0-11 \mathrm{~m}$ best developed in Gozo

Mbc - Blue Clay: Pale to grey soft pelagic marls $15-75 \mathrm{~m}$

Mug - Upper Globigerina Limestone Member : Yellow planktonic foraminiferal limestone with grey marl interbed $8-25 \mathrm{~m}$

Mmg - Middle Globigerina Limestone Member: White or grey fine foram-cocolith mudstones and marls $15-35 \mathrm{~m}$

Mlg - Lower Globigerina Limestone Member: Yellow or grey marly limestones at the base (locally known as soll) passing upward to cream limestone (Locally known as franka stone) $0-80 \mathrm{~m}$ thick

Om - II-Mara Member: Bedded pale cream to pale grey carbonate mudstones, wackestones and packstones best developed in eastern Malta

Fig. 2 - Stratigraphy of the Maltese Islands. (Mangion 2008).

Fig. 2 - Stratigrafia delle isole maltesi. (Mangion 2008).

formation which sustain floating lenses of groundwater in direct lateral and vertical contact with the underlying seawater, and hence highly vulnerable to sea-water intrusion in response to abstraction activities.

This conceptual understanding of groundwater development in the two aquifer typologies of the Maltese islands is presented in figure 3. The long term annual average abstraction from groundwater resources is estimated to reach around $40 \mathrm{Mm}^{3}$, which is around $60 \%$ of all the freshwater produced in the islands to address the national demand for water.

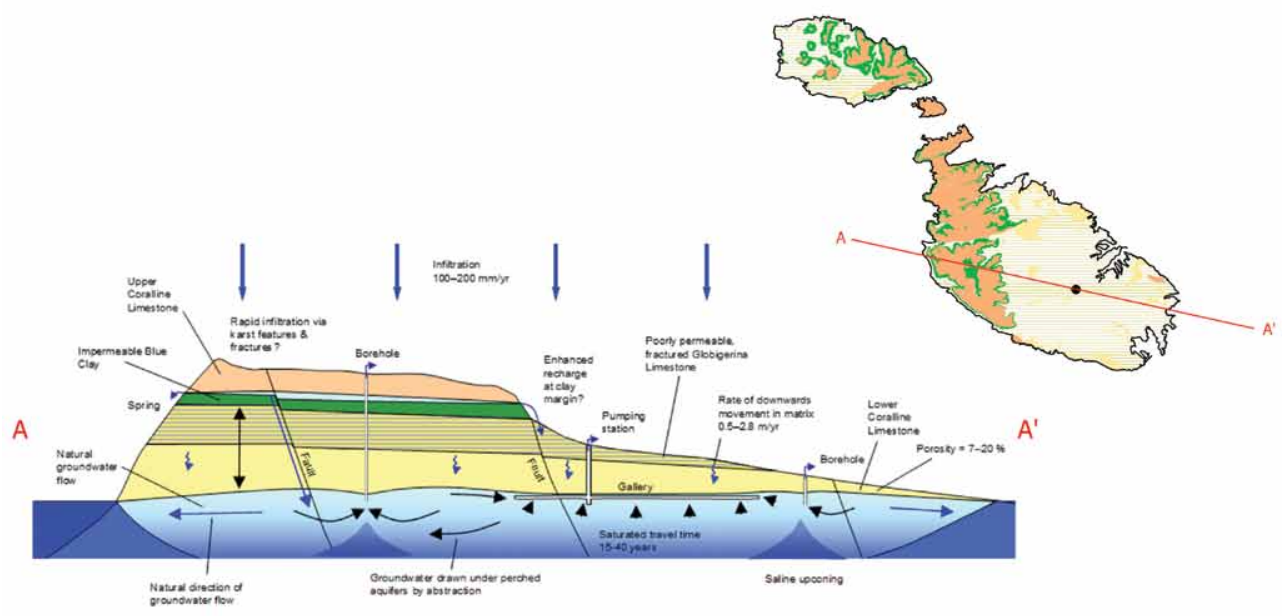

Fig. 3 - Conceptual understanding of groundwater systems in the Maltese islands (BGS 2008).

Fig. 3 - Schema del modello concettuale idrogeologico tipico delle isole maltesi (BGS 2008). 
The Water Exploitation Index (WEI+) is a commonly used indicator at EU level to gauge water stress. It has been defined as the percentage of the annual freshwater abstraction (both from surface and groundwater) over the long-term available freshwater resources. WEI+ calculations on a 'long term annual average' basis for the Maltese islands yield a value of $78 \%$ (Tab. 1), thereby confirming the water stressed nature of the aquifer systems. These levels should also be considered from the perspective that the EU considers a level of $40 \%$ WEI+ as indicating conditions of high water stress. (EWA 2015).

Natural water supplies are supplemented by Non Conventional Water Resources (NCWR) including the harvesting of rainwater, sea-water desalination and reuse of reclaimed waters. NCWR today, account for around $40 \%$ of the national water supply resource base which share is projected to increase to sustainably address increasing water demands. Desalination of sea-water is the most important NCWR in Malta contributing in 2019 an estimated annual volume of $20 \mathrm{Mm}^{3}$, with the harvesting of rainwater and water reuse contributing 7 and $2 \mathrm{Mm}^{3}$ respectively (Fig. 4).

\section{Water Resources - Supply Base}

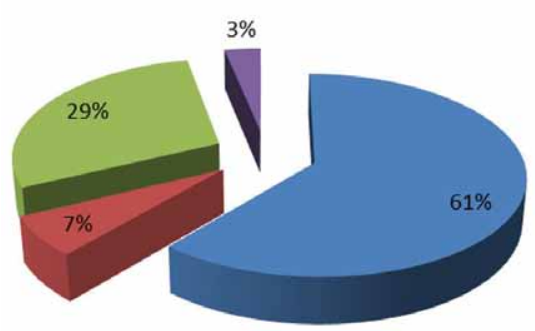

घroundwater

nainwater Harvesting

- Desalinated Water

wreated Sewage Effluent

Fig. 4 - Malta - Water Resources Supply Base (EWA 2015).

Fig. 4 - Fonti di approvvigionamento idrico (EWA 2015)

Harvesting of rainwater is a historical practice with the first rainwater harvesting structures being traced back to the Neolithic Period (Fig. 5). Throughout the ages, rainwater harvesting continued to be an important source of water in particular when organised water production and distribution was limited. Today, harvesting of rainwater is undertaken at both a national and local (user) level. At a national level rainwater runoff is collected and managed through a series of small dams constructed along the main valley systems, which structures also permit a certain level of Managed Aquifer Recharge to the underlying sea-level aquifer systems. At a local level, legislation requires the development of rainwater harvesting cisterns with every new urban development, whilst policy guidance encourages the development of small on-field reservoir systems in the agricultural sector. National and EU (FPD 2014) financing schemes are also utilised to support the undertaking of such works.

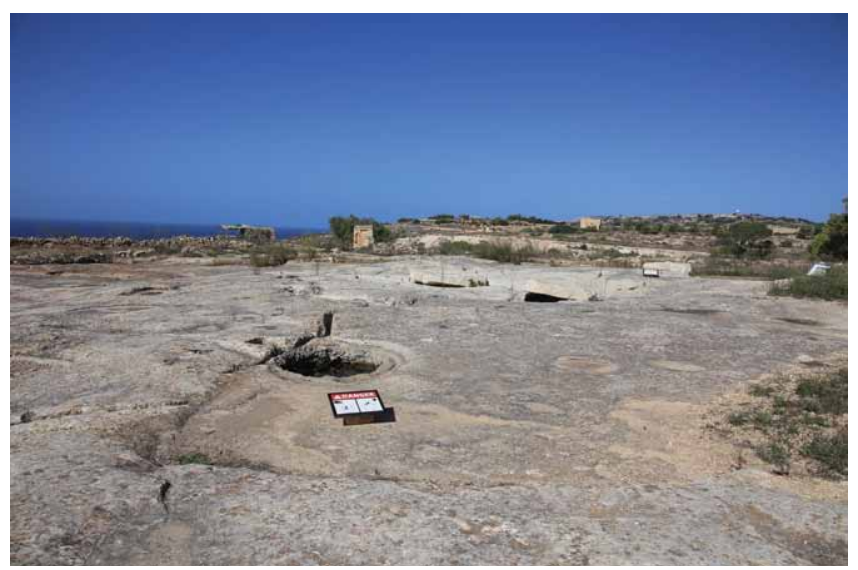

Fig. 5 - Rock-cut rainwater harvesting cisterns in the vicinity of the 'Mnajdra' Megalithic Temples which are generally presumed to be contemporary to the temples.

Fig. 5 - Cisterne per la raccolta dell'acqua piovana scavate nella roccia nelle vicinanze dei templi megalitici 'Mnajdra', che sono presunte essere contemporanee ai templi.

Desalination of sea-water has progressively become one of the most important sources of freshwater in Malta, today accounting for more than $60 \%$ of the public drinking water supply (EWA 2015). The need for augmenting potable water supply by desalinated water has long been felt with the first application of desalination technologies dating back to the 1880's (Morris 1952). Large scale application of desalination technologies can be traced back to the 1960's when multistage flash distillation plants were developed in both of the main islands. The increase in the price of oil in the late 1970's resulted in significant increases in the cost of water production, and marked the move to less-energy intensive reverse osmosis technology. The first membrane-based reverse-osmosis plant

Tab. 1 - Estimation of WEI+Long Term Annual Average (LTAA) and 2019 for the Maltese islands.

Tab. 1 - Stima dell'indicatore WEI+ per le isole maltesi, come media sul lungo periodo (LTAA) e nel 2019.

\begin{tabular}{|c|c|c|c|}
\hline Parameter & LTAA & 2019 & Comments \\
\hline Precipitation $\left(\mathrm{hm}^{3}\right)$ & 174 & 170 & \\
\hline Actual Evapotranspiration $\left(\mathrm{hm}^{3}\right)$ & 109 & 107 & assumed at $63 \%$ of total precipitation in both cases \\
\hline Renewable Water Resources $\left(\mathrm{hm}^{3}\right)$ & 65 & 63 & \\
\hline Natural Subsurface Discharge $\left(\mathrm{hm}^{3}\right)$ & 24 & 24 & assumed at $50 \%$ of the long term annual recharge to the MSLA systems \\
\hline Unrecoverable Surface Runoff $\left(\mathrm{hm}^{3}\right)$ & 4 & 4 & estimated at $25 \%$ of total surface runoff generated (initial estimate) \\
\hline Actual available Water Resources $\left(\mathrm{hm}^{3}\right)$ & 37 & 35 & \\
\hline Total Abstraction / Utilisation $\left(\mathrm{hm}^{3}\right)$ & 38 & 41 & \\
\hline Returned Water $\left(\mathrm{hm}^{3}\right)$ & 12 & 11 & return from municipal supply leakages and irrigation \\
\hline WEI+ & $78 \%$ & $89 \%$ & \\
\hline
\end{tabular}


was if fact commissioned at Ghar Lapsi in 1982. At that time, this plant with an installed production capacity of 20,000 $\mathrm{m}^{3} /$ day was one of the first applications of reverse-osmosis technology on a commercial scale and the largest plant in the Mediterranean (Andrews 1983). Throughout the years, additional desalination plants have been developed, to enable public water supply to be met whilst reducing pressures on groundwater resources. The Water Services Corporation WSC (Malta's public water utility) has been at the forefront of adapting and improving this technology with a view of bettering its economic and environmental performance. Key achievements include:

i. the reduction of the specific energy of desalination plants (the energy required to desalinate $1 \mathrm{~m}^{3}$ of sea-water) from 6 to $3 \mathrm{kWh}$ over the last 10-year period (Fig. 6), through the upgrading of membrane and energy recovery technologies (WSC 2019)

ii. the development of in-house management systems which enable the most-efficient membrane units to be utilised thereby enabling the continued use of the most costeffective production layout (WSC 2019).

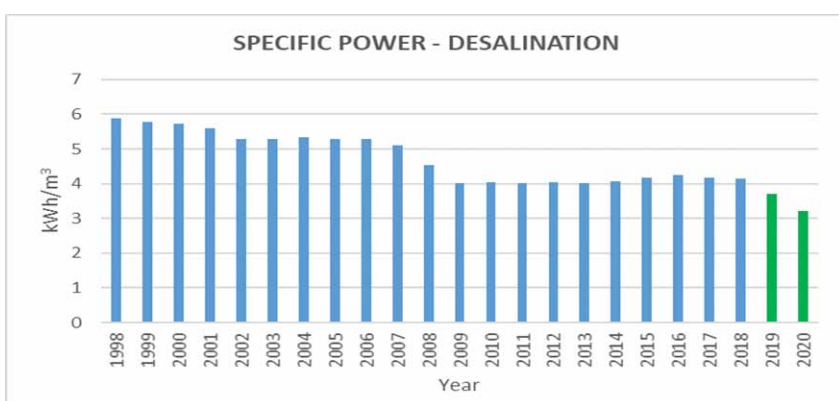

Fig. 6 - Reduction in the Specific Energy Requirements for Sea-Water Desalination at WSC's Reverse Osmosis Plants. (WSC 2019).

Fig. 6 - Riduzione del fabbisogno energetico necessario per la desalinizzazione dell'acqua di mare tramite gli impianti di osmosi inversa del WSC. (WSC 2019).

In recent years, the Water Services Corporation, through its New Water programme has also invested in the development of facilities for the further polishing of treated wastewater in order to enable its utilisation in the agricultural and commercial sectors in substitution of groundwater resources. A highend technological process has been developed which enables reclaimed water from the Urban Wastewater Treatment Plants to pass through an additional three-barrier process - namely Ultrafiltration, low-pressure Reverse Osmosis and Advanced Oxidation in order to ensure high quality levels in the polished effluent product (Fig. 7). In particular, the presence of an all year-round supply of good quality irrigation water increases security of supply to the agricultural sector thereby increasing the crop production capacity and hence further contributing to food security whilst also facilitating further investments in the development of the sector, including in optimising its water use efficiency. Malta's New Water programme aims to produce an annual volume of 7 million $\mathrm{m}^{3}$ of reclaimed water aimed at part-addressing the water demand of the agricultural, landscaping and industrial sectors. Automated distribution systems and an incentive pricing framework are being used to ensure that use of this water is undertaken in as an efficient way as possible (EWA 2015).

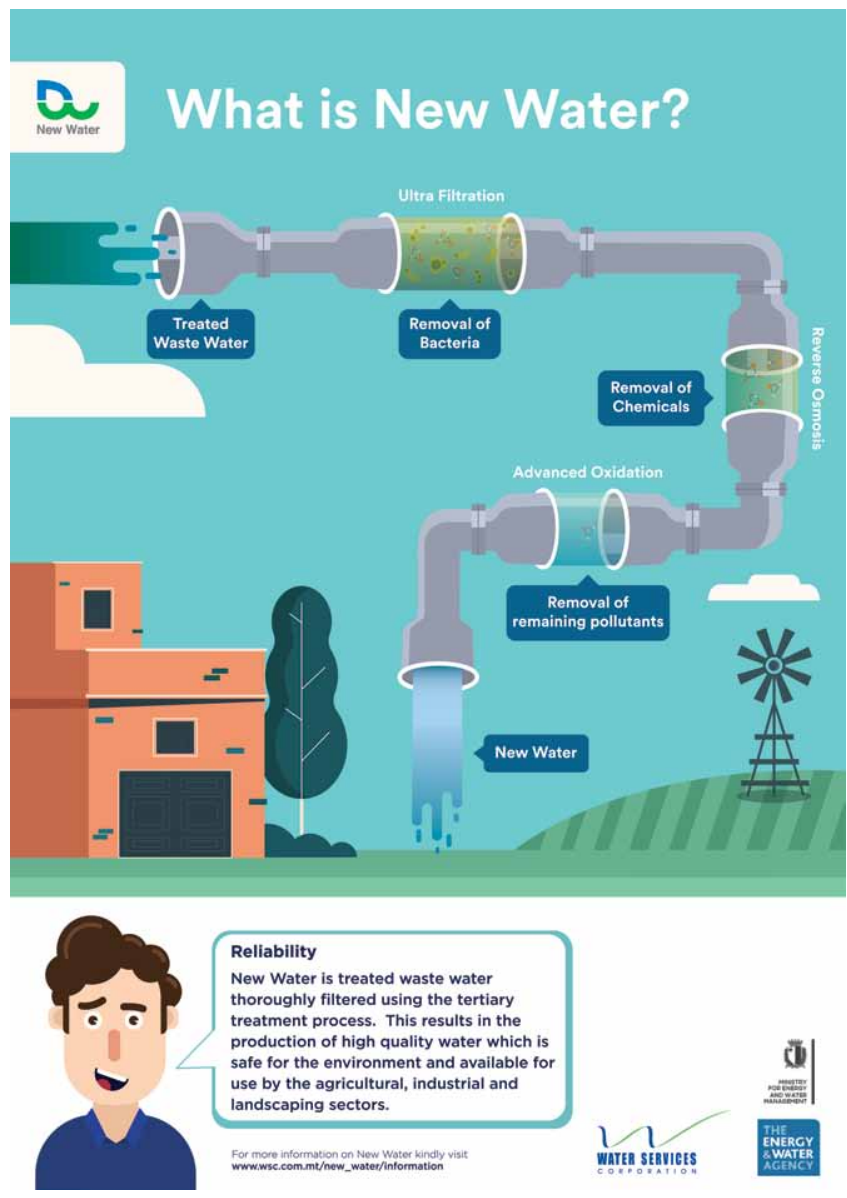

Fig. 7 - Schematic representation of the New Water treatment process.

Fig. 7 - Rappresentazione schematica del nuovo processo di trattamento denominato New Water.

\section{Water Demand Management}

Ensuring the achievement of highly efficient water use levels is an important cornerstone of Malta's water management strategy. Managing water demand and ensuring that consumption is controlled reduces the need for the additional production of water resources, hence reducing pressures on natural water resources and the national water supply framework. Water demand management techniques are applied at both a national and a user level. Whilst at a national level the interventions focus on addressing system demand, at a user level interventions focus primarily on the reduction of the actual water used.

On a national level, water demand management measures are primarily focused on the reduction of losses (leakages) in the municipal water distribution network. Impressive results have been achieved by the WSC in this sector, where since the start of an aggressive leakage management and repair programme in the 1990's overall municipal water demand has 
been reduced by around 40\% (EWA 2015). In fact, municipal water demand today stands at around $60 \%$ of the demand levels registered in the early 1990's (Fig. 8), and this in spite of an increasing population and improving standard of living which are expected to contribute to an increasing per-capita demand. This reduction in the national water demand is reflected in lower groundwater abstraction levels and lower energy consumption in production and distribution by the public utility and hence also results in an important beneficial environmental impact. In fact, groundwater abstraction for municipal supply purposes decreased from around $21 \mathrm{Mm}^{3}$ in the early 1990's to around $13 \mathrm{Mm}^{3}$ in 2019 ; whilst the energy demand for water production decreased from $10 \%$ of the total national energy demand in the 1990's to less than $4 \%$ in 2019 (WSC 2019).

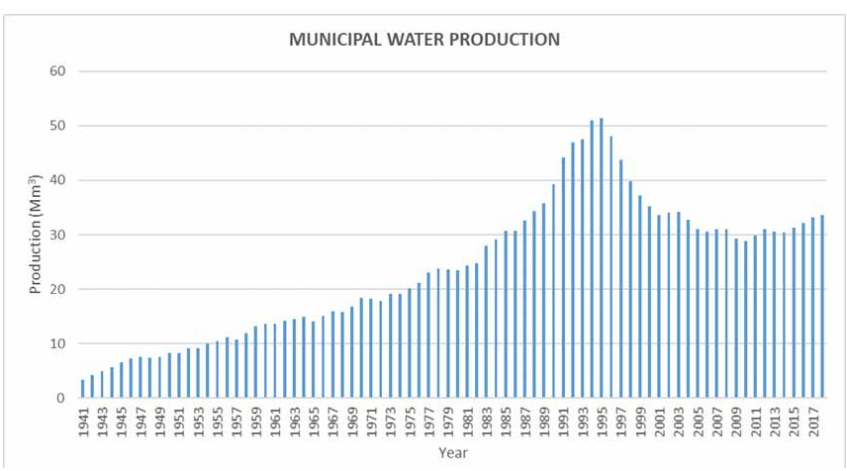

Fig. 8 - The application of an aggressive leakage management programme has reduced water production for municipal purposes by around 40\% (EWA 2015).

Fig. 8 - L'applicazione di un deciso programma di gestione delle perdite ha permesso di ridurre la produzione di acqua per usi municipali di circa il $40 \%$ (EWA 2015)

Importantly as well, as a result of a continued programme of active engagement with the population through a National Water Conservation Campaign (www.ilma.org.mt) Malta presents one of the lowest per capita water consumption levels in Europe. This is further supported by interactive educational activities on water demand management for schools such as those undertaken at the National Water Conservation Awareness Centre (GHAJN - www.energywateragency.gov. $\mathrm{mt} / \mathrm{ghajn})$. In fact, mean per-capita water consumption levels stand at around 110 litres/person/day. Water consumption has also been effectively managed through a rising-block tariff mechanism which increases the applicable tariff from Eur $1.39 / \mathrm{m}^{3}$ to Eur $5.14 / \mathrm{m}^{3}$ for water consumption per capita exceeding the 90 litres/person/day threshold.

Still, more can be done to increase the efficiency of water consumption in the domestic sector given that around $70 \%$ of water used in households is today directed towards hygiene related uses (Tab. 2). Greywater recycling such as by diverting shower water to toilet flushing, provides important opportunities for promoting the continued reduction of effective per capita water use, and the adaptation of such practices features strongly on Malta's future water policy outlook.
Tab. 2 - Water Use Characteristics in Maltese Households (EWA 2015).

Tab. 2 - Tipologie di utilizzo dell'acqua in ambito domestico (EWA 2015).

\begin{tabular}{|l|c|}
\hline \multicolumn{1}{|c|}{ Domestic Use Typology } & Litres/person/day \\
\hline Personal Hygiene & 34 \\
\hline Toilet Flushing & 26 \\
\hline Laundry & 17 \\
\hline Dish Washing & 13 \\
\hline Drinking and Cooking & 6 \\
\hline Others & 14 \\
\hline
\end{tabular}

As one of the main water demanding sectors, water demand management measures focus also on the agricultural sector. In this regard, incentive and support programmes have helped the sector to invest in highly efficient water irrigation technology, where today drip-irrigation technologies are applied to around $90 \%$ of all irrigated land. Support mechanisms such as financial and technical assistance programmes are also in place to incentivise the introduction of new technologies, such as advanced irrigation systems, to assist (guide) sector in becoming more efficient in its use of water. Here, in line with the requirements of the Common Agricultural Policy, approval of investment support relies on the ability of the applicant to effectively reach a quantified water saving impact.

Efforts are also ongoing to enable a better management of groundwater use by the agricultural sector through the progressive metering of groundwater abstraction sources. Remote monitoring frameworks which enable comparative analysis of water use and agricultural land-use are also being developed to enable inefficient water uses by the sector to be quickly identified and addressed (EWA 2015). Analytical methods for the estimation of irrigation water demand at holding level through the use of satellite imagery are currently being developed through the WARM-EO Project, a joint research initiative between EWA and the University of Malta. Comparative correlations between this remotely acquired data and water metering data collected from volumetric meters installed on groundwater abstraction sources will enable the identification of wasteful water users, who can then be supported to better manage their water use.

\section{$2^{\text {nd }}$ River Basin Management Plan}

This water management policy framework is outlined in Malta's $2^{\text {nd }}$ RBMP, published in 2015 as part of the national implementation process of the EU Water Framework Directive, which under its "Programme of Measures" develops a set of actions the implementation of which aims to ensure that the national water demand is met whilst ensuring the sustainable use of natural freshwater resources by 2021 (Fig. 9). The implementation of these actions enables continued investment in water demand management measures and the development of alternative water supplies.

In particular the $2^{\text {nd }} \mathrm{RBMP}$ focuses on the broadening of the water services portfolio offered by the public utility to 

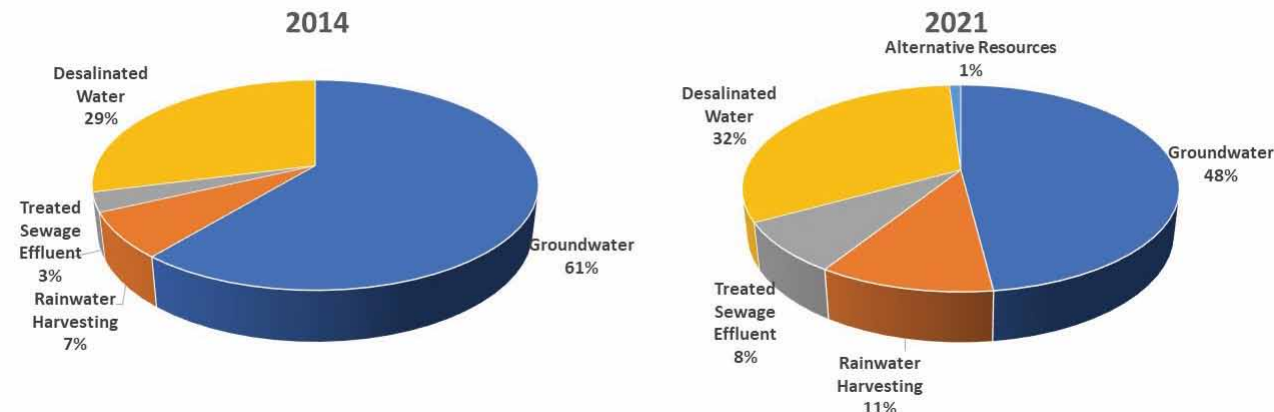

Fig. 9 - Malta's $2^{\text {nd }}$ RBMP aims to modify Malta's water supply resource base to ensure security of supply whilst ensuring the sustainable use of natural water resources (EWA 2015).

Fig. 9 - Il secondo piano di bacino (2 nd RBMP) ha l'obiettivo di modificare la tipologia di approvvigionamento delle risorse idriche di Malta per garantire la sicurezza dell'approvvigionamento assicurando al contempo l'uso sostenibile delle risorse idriche naturali (EWA 2015).

enable the reformulation of its operational practices with the aim of developing it into a Net-Zero Impact Water Utility (WSC 2018). This concept sees the water utility give back to the natural water environment, at least, as much water as the groundwater it abstracts from the aquifer systems as part of its operations. This through intended and unintended aquifer recharge and the supply of treated wastewaters to be used in substitution of groundwater. In this way, the environmental footprint of the water utility on the water environment is being lowered with the aim of progressively achieving a neutral impact. This project which is part-financed by the European Union's Cohesion and Rural Development Funds is currently under implementation and will be concluded in 2022. It sees an investment of over Eur 150 million in the operations of the WSC including the optimisation of desalination plants, the reformulation of distribution systems, including the development of a dedicated distribution system for reclaimed water, and the optimisation of the quality of drinking water supplied to consumers.

The Net-Zero Impact framework has also focused on the energy use of the utility, where investments in the continued upgrading of desalination plants, the water distribution network, wastewater collection and treatment systems also take due consideration of reducing the energy requirements for water services provision. This operational framework aims to continually decrease the specific power of water service provision, and thereby enable any increased production to address water demand to be met without increasing the overall net power requirements of the water utility. The adoption of this operational set-up has throughout the years seen the provision of municipal water supply reduce its share of national electricity consumption from 12 to $6 \%$.

The $2^{\text {nd }} \mathrm{RBMP}$ also provides added focus on the development of a strong engagement process with stakeholders, in order to enable the effective contribution of water managers, water users and supporting organisations in ensuring the effective implementation of its "Programme of Measures". In fact it establishes an Inter-Ministerial Committee which is tasked to coordinate the implementation of measures which involves representatives of all Ministries who directly or indirectly have a role in the management and use of water resources.
In addition a National Water Table has been established under the $2^{\text {nd }}$ RBMP where representatives of the public and private sector discuss the implementation of the River Basin Management Plan. This National Water Table thus brings together representatives from the public sector at policy, regulatory and operational level and representatives of stakeholder organisations in the agriculture, fisheries, tourism and recreational sectors and environmental voluntary organisations. The discussions in the Water Table have provided a key-feedback loop enabling the optimisation of measures and hence supporting public entities in ensuring the effective implementation of these measures,

The impact of Climate Change on the water sector is an additional important challenge which Malta's water management framework will need to increasingly take into consideration in the future years. Higher temperatures, lower annual precipitation, and an increase in high intensity rainfall events are all factors which are having a determining impact on the national water sector, which is already vulnerable due to the prevailing semi-arid climate. Applying UNEP's Aridity Index to long-term climatic data, classifies Malta's climatic conditions, with a score of 0.39 , within the semiarid climate band (EWA 2015). Malta's water management framework, through its comprehensive supply augmentation/ demand management approach, aims however to turn these additional challenges to opportunities for further developing the resilience of the water sector in addressing and adapting to a more difficult environment. This will be achieved through the development of increasingly comprehensive water management frameworks, specifically suited for semiarid islands or coastal regions which ensure the development of measures which are specifically adapted to the particular characteristics of these areas and define new opportunities for improving water resources management. Of particular reference in this regard is the LIFE Integrated Project "Optimising the Implementation of the $2^{\text {nd }} \mathrm{RBMP}$ in the Malta River Basin District" (www.rbmplife.org.mt), which is an eight year project led by the Energy and Water Agency and co-financed under the EU LIFE Programme which aims to support the implementation of the Water Framework Directive in Malta. Although this project works on the development of a 
comprehensive water management framework for the Maltese islands, it has a strong replication component to enable its results to be presented to other islands or coastal regions facing similar challenges in the Mediterranean Region. This project thus has also a regional dimension which highlights the need for increased cooperation between water managers at the Mediterranean level to develop regional specific solution based on available knowledge and experiences.

\section{Conclusion}

Malta has developed a national water policy framework which considers water management from a starting point of unavailability of sufficient natural freshwater resources to meet the water demands. The policy framework seeks to ensure the development of an adequate supply of water to address the needs of the population and their economic activities whilst respecting the needs of the environment.

This water management framework considers the specific conditions prevailing in islands and coastal areas having prevailing semi-arid climatic conditions, and hence can be considered as a blue-print which can be applied in territories facing similar water management challenges to those being experienced by Malta. Such territories include major Mediterranean islands such as Cyprus, Crete and the Balearic Islands, as well as other smaller islands such as Lampedusa and the Greek islands. This since the policy framework is based on the development of a comprehensive approach which leads to the identification of a set of tools (measures) which take full consideration of (specific) environmental, social and financial aspects to identify the best implementable solutions and hence is sufficiently flexible to be adapted and adopted in similar islands and regions.

\section{REFERENCES}

Andrews WT, Sleigh JH, Bergman R (1983) The Malta seawater reverse osmosis facility. Desalination, Volume 46, Issues 1-3, May 1983, Page 111.

BGS (2008) A Preliminary Study on the Identification of the Sources of Nitrate Contamination in Groundwater in Malta Results and Interpretation. British Geological Survey, UK.

EWA (2015) Second Water Catchment Management Plan for the Malta Water Catchment District 2015-2021. Energy and Water Agency, Malta.

FPD (2014) The Rural Development Programme for Malta. Funds and Programmes Division, Ministry for European Affairs and Equality, Malta

Mangion J, Sapiano M (2008) The Mean Sea Level Aquifer, Malta and Gozo. in Natural Groundwater Quality, Blackwell Publishing 400-420.

Martinelli M, Bistacchi A, Balsamo F, Meda M (2019) Late Oligocene to Pliocene Extension in the Maltese Islands and Implications for Geodynamics of the Pantelleria Rift and Pelagian Platform. Tectonics, 38(9): 3394-3415.

MEPA/MRA (2011) The Water Catchment Management Plan for the Maltese Islands, March 2011. Malta Environment and Planning Authority \& Malta Resources Authority, Malta.

Morris TO (1952) The Water Supply Resources of Malta, Government Printing Press, Malta

NSO (2020) Regional Statistics, Malta - 2020 Edition. National Statistics Office, Malta

Sapiano M, Mangion J, Batchelor C (2006) Malta Water Resources Review. Food and Agriculture Organization, Rome. https://agris.fao. org/agris-search/search.do?recordID=XF2007429937.

Sapiano M, Micallef P, Attard G, Zammit ML (2008) The evolution of water culture in Malta: an analysis of the changing perceptions towards water throughout the ages. Options Méditerranéennes, 83, 97-109.

WSC (2019, 2018, 2017) The Annual Report. Water Services Corporation, Malta. 